\title{
O QUE A AMIZADE (PHILIA) NOS DIZ SOBRE OS FUNDAMENTOS DA DEMOCRACIA? PRESSUPOSTOS DE UMA “DEMOFILIA"1
}

\author{
Thais Florencio de Aguiar \\ é professora do Departamento de Ciência Política da Universidade Federal do Rio de Janeiro \\ (UFRJ).Rio de Janeiro, RJ, Brasil. E-mail: thais.aguiar@gmail.com
}

Orcid: 0000-0002-7951-7920

http://dx.doi.org/10.1590/0102-091125/107

\section{Introdução}

A palavra philia ( $\varphi \imath \lambda i \alpha)$, embora traduzida por amizade, pode ser entendida como tipo para todas as afeições, consistindo na afeição-matriz mais forte e desenvolvida na cultura da Grécia Antiga. Segundo Macherey (1995), ela eclipsa inclusive o amor, o que significa que a extensão dada ao amor pelas teorias morais modernas equivale à extensão atribuída à philia pelos gregos antigos. Assim, se na modernidade se fala em amor paternal, amor filial, na Antiguidade os gregos diziam philia paternal, philia filial. Adotando a tradução costumeira de philia por amizade ou algo próximo disso (desde que nos desvencilhemos da acepção moderna), podemos falar assim em amizade paternal, amizade filial etc. De difícil tradução, philia parece denotar certa relação amistosa, que pode existir inclusive entre amantes (philia érotikê), sendo situada no campo semântico entre amizade e amor. Assim, o termo envolve também o amor do gênero humano (philantrôpia), o amor entre companheiros (philia hétairikê), a amizade entre concidadãos (politiké philia) (Konstan, 2005; Macherey, 1995). Evidencia-se nessa breve e limitada

\footnotetext{
1 Este trabalho foi realizado com apoio da Coordenação de Aperfeiçoamento de Pessoal de Nível Superior (Capes) - Código de Financiamento 001. Trata-se de artigo que consiste em reformulação e desdobramento de argumento apresentado no quinto capítulo do livro Demofobia e demofilia: dilemas da democratização (Aguiar, 2015).
} 
incursão semântica a importância da philia-amizade para os homens na Antiguidade.

O objetivo principal deste artigo é explorar os sentidos subentendidos do conceito de philia, sua ligação com a pólis grega e com a democracia antiga e, em menor grau, esboçar os sinais de sua presença na construção política da modernidade. A principal referência é o pensamento de Aristóteles. Como ressalta Gobry (2000), Aristóteles é o pensador que estuda a philia com maior interesse e amplitude, fazendo de dois dos dez livros de Ética a Nicômaco (livros VIII e IX) um verdadeiro tratado sobre o tema. Por essa razão, a concepção de philia formulada pelo estagirita estabelece-se como paradigma. É preciso frisar desde já que a concepção presente na obra do mestre grego não consiste apenas em registro da teoria e da prática da philia manifestadas em dado momento histórico da vida ateniense. Ela exprime uma formulação própria ao autor, distanciada, por exemplo, da noção de seu mestre Platão.

Este artigo está organizado em três momentos. O primeiro dedica-se a extrair da philia aristotélica alguns traços ou pressupostos centrais de sua concepção. Em seguida, assimilando a política como continuação da investigação ética, apreendemos a philia como pressuposto inarredável do plano ético-político, fundamento da constituição da pólis. $\mathrm{O}$ segundo momento concentra-se em pensar a afinidade existente entre philia e democracia apontada por Aristóteles, bem como investigar a transmutação da amizade em fraternidade na democracia moderna, esboçando brevemente os sinais recônditos da persistência de pressupostos da philia na gramática da democracia moderna.

\section{A relação entre philia e pólis}

\section{O sentido da philia e a derivação de suas proposições}

Em Aristóteles, o uso da palavra philia designa, da mesma forma, mais do que aquilo que entendemos a partir 
da modernidade por amizade. Os mais diversos vínculos são expressos nessa pequena palavra grega, incluindo os amigos, os parentes e até os concidadãos ou os membros de associações. O sentido contido na palavra usada por Aristóteles, portanto, envolve "a natureza dos laços ou relações afetivas em geral” (Konstan, 2005, p. 97). Em Ética a Nicômaco, fica perceptível que se trata de um termo que engloba as mais variadas dimensões. A primeira dimensão a destacar é a de que a presença da philia não se restringe ao plano privado ou público das relações, de modo que Aristóteles menciona a philia existente entre uma mãe e um filho, ao mesmo tempo em que aborda a philia que emerge provisoriamente entre companheiros de viagens e a philia entre os cidadãos da pólis. De certo, ela constitui um objeto da ética, mas apresenta igualmente relação inequívoca com a política. Por isso mesmo a philia ocupa um papel central em Ética a Nicômaco, constituindo o tema de dois dos dez capítulos da obra, não tendo de nenhuma maneira papel secundário em Política.

Desse modo, a concepção de philia, na verdade, atravessa as fronteiras entre os estudos éticos e políticos em Aristóteles - bem como na grande parte dos pensadores da Antiguidade. Essa observação está, aliás, em consonância com a hipótese bem conhecida de que Ética a Nicômaco e Política constituem uma só e mesma obra, a divisão em dois livros distintos seria mera decisão arbitrária de discípulos do mestre. Indubitavelmente, a noção de philia apresentada em Ética a Nicômaco é de extrema importância para entendimento de noções apresentadas em Política. Com efeito, conforme lemos em Ética a Nicômaco, ética e política são consideradas dimensões inseparáveis, a ética sendo concebida como parte da política, designada como "ciência arquitetônica". Esse laço inarredável fica evidente ao longo da obra aristotélica, a qual propõe, nos termos de Aubenque (2003, p. 92), "a reintegração da experiência política na experiência moral da humanidade”. Por essa razão, a philia se estabelece como 
um conceito de natureza ético-política, exprimindo mais do que um vínculo afetivo, um determinado regime relacional de expressão política. Nesse sentido, sem uma noção desenvolvida de philia, a compreensão de aspectos fundamentais das concepções de pólis e de democracia fica comprometida.

Antes de explorarmos a ligação entre philia, pólis e democracia, atentemos primeiramente à concepção aristotélica de philia, destacando três características que consideramos centrais.

A primeira característica diz respeito à afirmação da igualdade como traço essencial da philia-amizade. Aristóteles constrói esse traço partindo da seguinte ideia: o amigo (ou praticante da philia) ama o que é bom para si, na mesma medida em que deseja o bem e proporciona o prazer aos amigos $^{2}$ (Aristote, 1987, VIII, 5). Dessa maneira, o homem virtuoso "torna-se um bem" para aquele que é seu amigo (Aristote, 1987, VIII, 7). Aristóteles estabelece na relação de igualdade uma equivalência ou reciprocidade, pela qual dois amigos que amam o seu próprio bem dão ao outro exatamente o que recebem. Trata-se de um gesto de retribuição, sem ser uma compensação. Em Aristóteles, desejar aos outros os mesmos bens em reciprocidade ou ainda trocar uma coisa por outra (sem necessariamente ser da mesma espécie) caracteriza a amizade como um tipo de igualdade. Importante ressaltar então que a relação de philia se caracteriza por prezar pelo máximo de igualdade possível.

Aristóteles formula o traço da igualdade ainda de outra maneira, mobilizando elementos da tradição pitagórica, tão enraizada na cultura grega: o amigo é concebido como "o meu igual". Conceber o outro como o meu igual equivale

\footnotetext{
${ }^{2}$ Usamos como obra de referência para essas citações a publicação de Ética a Nicômaco introduzida, anotada e traduzida em francês por Tricot (Aristote, 1987). Alertamos que a ordenação das partes do texto pode variar de acordo com a edição. O número referente às linhas na obra é indicado apenas quando ocorre citação literal.
} 
a conceber como Epicuro o concebeu na carta a Meneceu: "a sociedade de amigos, isto é, de semelhantes". Considerar o amigo como "outro eu" corresponde também a considerá-lo como parte de si próprio e, como nota Fraisse (1974), isso não deixa de ser o embotamento da antítese entre altruísmo e egoísmo. A partir do encadeamento desses termos que dão feição ao traço da igualdade, podemos afirmar que o princípio da igualização constitui condição sine qua non da existência da amizade. Derivamos da argumentação de Aristóteles a seguinte proposição: sem igualdade não existe amizade. Dito de outra forma: se a amizade supõe a igualdade, onde houver desigualdade, menos presente se faz amizade. Por conseguinte, onde a amizade for restrita, mais desigualdade se amplia.

Com efeito, a philia, ou amizade, praticamente não existe entre pessoas de escalão muito desigual ou em condições de desigualdade (Aristote, 1987, VIII, 9). Na realidade, para Aristóteles, a amizade entre desiguais pode existir, mas sem implicar virtude, ou seja, expressar a excelência do homem, o que é próprio da philia virtuosa. Essa amizade é costumeiramente de segunda ordem, ou seja, uma amizade menor, esvaecente, porque motivada por utilidade ou vantagem. Trata-se de uma philia muito provisória, que une complementares até onde se estende a vantagem buscada. A relação entre o homem e deus serve de maior ilustração da desigualdade de escalão. Nessa relação, a desigualdade é tão demasiada que a amizade entre eles se torna, na verdade, impossível (proposição que Aristóteles sustenta em oposição ao pensamento de seu mestre Platão).

A segunda característica da philia concerne ao traço essencial de dispor a vida e as coisas em comum. "Nada, com efeito, caracteriza melhor a amizade que a vida em comum", define Aristóteles (Aristote, 1987, VIII, 6, 1157 b 18, tradução nossa). A vida em comum apresenta pelo menos dois significados fortes. Ela significa negar a solidão que, frisa 
Aristóteles, não convém a ninguém: mesmo as pessoas mais ocupadas desejam passar o tempo junto a outros, mesmo os mais sábios, mesmo os mais ricos, mesmo os mais felizes dão sentido à vida compartilhando tempo, conhecimento, riqueza e felicidade. Vida em comum implica também afirmação da prática de partilha: aqueles que passam por necessidade aspiram à ajuda de amigos e aqueles que compartem gostos comuns formam associações ou comunidades de camaradagem. ${ }^{3}$ Por isso, Aristóteles afirma peremptoriamente que "a amizade consiste em um pôr em comum" (Aristote, 1987, VIII, 11, 1159 b 33-34, tradução nossa). A vida em comum é algo da ordem não só do necessário, na medida em que o auxílio mútuo está no cerne da vida na pólis, bem como do desejável. A prática de "pôr em comum" faz com que "a amizade [seja], com efeito, uma comunidade" (Aristote, 1987, IX, 12, 1171 b 30-35, tradução nossa).

Na concepção aristotélica, o pôr em comum se inscreve na amizade determinando alguma comunhão de bens (Aristote, 1987, VIII, 9). A inspiração aqui, mais uma vez, deriva da máxima pitagórica "os amigos têm bens em comum" ou "tudo é comum entre amigos". Essa noção pode ser estendida no sentido de formar uma comunidade de bens corporais ou materiais, bem como de pensamentos ou sentimentos. Uma coisa Aristóteles deixa claro: a amizade é perfeita quando os mais diversos elementos são postos em comum. Para ele, toda comunidade diz respeito a uma amizade. Isso quer dizer que toda comunidade envolve amizade, de modo que não são os amigos que, necessariamente, dão origem à comunidade, mas a comunidade que dá lugar às amizades. "A eleição da vida em comum supõe a amizade

\footnotetext{
${ }^{3}$ Em sua tradução de Ética a Nicômaco para o francês, Tricot esclarece que camaradagem designa espécie de amizade ou de associação. Em Retórica (II, 4, 1381 b 34), camaradagem diz respeito a grupo de pessoas que professam gostos comuns e colocam uma parte de seus recursos à disposição dos coassociados (cf. Aristote, 1987, VIII, 6).
} 
[...]" (Aristóteles, 2000, III, 91280 b 33-39). Derivamos, portanto, do pensamento aristotélico esta proposição: a philia, ou amizade, está tanto mais presente quanto mais intensamente a vida é disposta em comum, o que caracteriza, por conseguinte, a comunidade e a própria vida na pólis.

A terceira característica refere-se à consciência de si que emerge a partir da consciência de existência de seus amigos e da participação na consciência que seu amigo tem de sua própria existência. Essa consciência se torna ativa quando incitado o desejo fundamental de convivência, que se traduz pela vivência em comum e pela partilha de discussões e de pensamentos. É imprescindível destacar o sentido marcante que Aristóteles confere então à convivência entre homens, pois para o pensador, "[...] é nesse sentido, parece, que se deve falar de vida em sociedade quando se trata de homens, e, não, quando como se trata de gado, cuja existência consiste somente em pastar juntos no mesmo lugar" (Aristote, 1987, IX, 9, 1170 b 10-15, tradução nossa). Com efeito, a convivência (com-vivência) implica partilha, atividade de cooperação, isto é, ação conjunta em vista de um bem comum. Dessa forma, Aristóteles afasta qualquer sentido reducionista que traduza a convivência por um mero sentimento gregário. Nesses termos, a philia se inscreve como marca da humanidade, uma vez que sem ela os homens se assemelham ao rebanho animal. A distinção é muito simples: os animais vivem em bando, os homens vivem em comunidade. A convivência é obra da amizade (Aristóteles, 2000, III, 5).

A proposição em torno da consciência de existência comum parece ser tão importante que Aristóteles, já no início do primeiro livro sobre amizade, faz uma clara alusão ao provérbio homérico, retirado desta vez de Odisseia: com amigos, "dois que andam juntos, os homens são mais capazes de ao mesmo tempo pensar e agir" (Aristote, 1987, VIII, 1, 1155 a 15). Pensar e agir, razão e ação consistem em 
dimensões específicas da política ou da vida na pólis. "Com" e não "sem"; "com" e não "contra”. Divisamos nessa construção que a convivência própria da amizade denota uma composição e não uma contraposição, que permite expressar não propriamente uma dominação, mas uma coordenação ou coparticipação que se conjuga como melhor forma de agir racionalmente na vida. Ao mesmo tempo, desenvolver a consciência de si pela consciência do outro corresponde conhecer mais a si mesmo em relação com o outro, saber se conduzir com o outro, distanciar-se da heteronomia. Não seria um requisito fundamental para, em outros termos, autonomizar-se em companhia do amigo?

Essa reflexão não está expressa nesses termos em Aristóteles, é verdade. Mas podemos extraílla, ampliando seus argumentos. Derivando do traço da convivência da philia a consideração da dominação como inadequação, podemos compreender que ela seja a negação da própria vida em comum. Essa perspectiva se encontra com a de Fraisse (1974, p. 247), para quem a consciência de existência comum concerne diretamente à condição da felicidade (eudaimonía) como perfeição ética resultante da vida virtuosa. Convém notar que todas as proposições tocantes à philia estão reunidas na mensagem que ecoa da obra de Aristóteles, qual seja, a de que a excelência não pode ser praticada por eremitas. O indivíduo isolado e atomizado não é autossuficiente: o homem sem pólis é um ser desprezível ou supra-humano (Aristóteles, 2000, I, 1). Como a mais potente das comunidades, a pólis constitui o lugar do exercício conjunto da virtude e, por conseguinte, da excelência construída na prática da vida em comum. Para Aristóteles, como veremos, essa é a única via para a autarquia.

\section{A philia como prática ético-política e condição da autarquia}

Destacadas as três características ou os três traços fundamentais de noção de philia - amizade supõe igualdade (o outro eu, o semelhante); amizade supõe vida em comum 
(a comunidade); amizade supõe consciência comum de existência (a convivência ou a busca da autonomia) -, é preciso agora compreender o que significa afirmar que a philia caracteriza a relação entre os membros da pólis (politês) (Aristote, 1987, VIII, 11, 2000, III, 5 ).

A primeira questão a saltar aos olhos do leitor moderno é a ideia de que os membros da pólis estão ligados por meio da philia. Como pode Aristóteles conferir à philia uma extensão multitudinária, a ponto de apresentá-la como fundamento da relação dos membros da pólis? O próprio Aristóteles pondera essa questão quando afirma que não devemos viver sem amigos, nem ter um número excessivo deles (Aristote, 1987, IX, 10). Isso vale, sobretudo, para a amizade estruturada primeiramente na utilidade, na medida em que é no mínimo tarefa árdua a retribuição de serviços a muitas pessoas. Vale igualmente para a amizade fundada primordialmente no prazer, visto que um número relativamente modesto de amizades supre essa finalidade. Vale, inclusive, para a amizade perfeita, a amizade por virtude, pois como a convivência é característica marcante da amizade, ela deve se restringir ao maior número com que se possa conviver. Quem diz ter um número ilimitado de amigos, na verdade, é amigo de ninguém, um obsequioso. Como pode se tornar real a amizade na pólis multitudinária por natureza?

Se Aristóteles amplia a philia ao universo dos concidadãos, não é porque seja possível ser amigo de muitos. Mas aqui o problema se apresenta como meramente quantitativo: se a população da pólis era da ordem de milhares, o que dizer sobre a população das cidades atuais? Essa é justamente a questão, a pólis não pode ser pensada apenas no sentido de aglomeração urbana, nem como território ocupado por população, mas principalmente como comunidade ética e política (politiké koinonia), sem dispensar seu corpo cívico e corpo de governo (Bevort, 2007). Pensar a amizade na 
pólis ou amizade política conduz precipuamente a pensar os significados da noção de comunidade. Nesse sentido, a tradução de pólis por cidade-estado denuncia o quanto produzimos enviesamentos marcados por modernismos acerca de concepções da Antiguidade. Existe então uma história da história do mundo antigo, cristianizada no medieval e influenciada, na modernidade, pelo momento nacionalista, imperialista e orientalista do eurocentrismo, como mostram estudos de revisão histórica (entre outros trabalhos, o livro recente Unthinking the greek polis: Ancient Greek history beyond eurocentrism, de Kostas Vlassoupolos, e o artigo "Como entrou e como finalmente saiu de cena a democracia grega", de Luciano Canfora). Esse movimento historiográfico de revisão repõe o problema interpretativo no campo da ciência política, abalando, em certa medida, toda estrutura do pensamento político tributário da Antiguidade.

Antes de marcar as implicações do sentido de pólis 100 empregado por Aristóteles, vejamos com que propósito considerar a pólis do ponto de vista ético-político, após as rupturas produzidas pelos modernos - como Maquiavel, talvez o maior deles - na junção desses campos operada pelo pensador grego. A philia, ou amizade, tem a primazia de se constituir como uma virtude ética: a amizade é, "com efeito, uma virtude, ou vai acompanhada de uma virtude" (Aristote, 1987, 1155 a 1-5, tradução nossa), sendo ao mesmo tempo condição e consequência da vida virtuosa. Ela diz respeito a uma "disposição da natureza" ou "disposição de caráter" (héxis) (Aristote, 1987, VIII, 6). Todavia, ela não é uma determinação natural, assim como não é contrária à natureza (Aristote, 1987, II, 2). Como toda disposição, a philia necessita de condições específicas, isto é, condições políticas para ser posta em atividade. Como esclarece Ortega (2002, p. 37), ela tem o caráter de um hábito e expressa determinada ação moral e intelectual "baseada em uma decisão livre da vontade, em que cada um deseja o bem do outro". 
Animada pela ética, a política, tendo em vista o tema da virtude, busca fazer com que os cidadãos sejam "homens bons" (virtuosos), sabendo que os homens não se tornam bons pela teoria, e sim pela prática (Aristote, 1987, II, 4). A ética aristotélica está voltada, assim, para a prática, a atividade da mente voltada para a ação e não para a contemplação. A sua filosofia prática tem como objetivo oferecer razões para agir. Como "filosofia das coisas humanas" (Aristote, 1987, X, 1181 b 15), a política opera em função de um bem, o bem comum ou a vida boa.

Nessa perspectiva, a política constitui a continuação da investigação ética. Em Aristóteles, a philia ocupa "o lugar mais alto de sua ética" (Chaui, 2002, p. 338), o que nos leva a insistir em sua imprescindibilidade para a política. Quando hierarquiza as três formas de amizade, Aristóteles tem em mente um valor ético normativo para a política, embora reconheça que a mais nobre delas - a virtuosa -, envolva em certa medida a utilidade e o prazer. Aristóteles valoriza a amizade por virtude, tendo como espelho não exatamente um tipo sociológico (o homem de traços aristocráticos) e sim precisamente um tipo mítico (o personagem homérico). A hierarquização tem como função a busca de uma amizade que apresenta um fim em si mesmo (o amigo amado por si mesmo), e não um meio para atingir um fim (Ortega, 2002, p. 40). A crítica ao vínculo interessado, que toma o amigo como um meio, está sintetizada na visão aristotélica da amizade utilitária como própria de almas mercantis (Aristote, 1987, VIII, 7), uma crítica que teve uma recepção reativa por parte da filosofia escocesa, sobretudo naquela vertente associada aos princípios incorporados no liberalismo.

Retomemos a questão agora de outro ponto de vista e perguntemos: a pólis se constitui por que os homens são amigos ou os homens se tornam amigos em decorrência da constituição da pólis? Considerando que a unidade doméstica 
(oikos) e o vilarejo já constituem comunidades, ou seja, laços e vínculos de afeição anteriores à pólis, a resposta seria que ela se constitui porque os homens são amigos. Contudo, aprendemos em Política que o poder político não é continuidade do doméstico, essas comunidades na realidade apenas preparam os indivíduos para "a philia propriamente dita que só se realiza na Cidade" (Chaui, 2002, p. 338). Como tipo especial de comunidade (koinonia) que visa certo bem (Aristote, 1987, VIII, 11), a pólis envolve todas as comunidades e, portanto, articula todos os exercícios particulares de philia em razão da função arquitetônica da política, sendo a mais soberana e autárquica de todas as comunidades. Dessa forma, a vida ética só se realiza plenamente na pólis por meio de sua feição comunitária e política (politeia) que possibilita o exercício das virtudes morais e intelectuais (Chaui, 2002). Por certo, a pólis tem como efeito predispor à amizade.

A philia designa, em boa medida, o principal sentido 102 ético da pólis. O fundamento da constituição da pólis constitui a invenção do comum pela philia. Os amigos são iguais, logo, semelhantes. Mas é equivocado dizer que a pólis ou comunidade (koinonia) se origina propriamente da semelhança, quando na verdade é o inverso: o espírito de comunidade produz a semelhança. Ao comporem a pólis, como sublinha Vernant (2011), os cidadãos tornam-se de certa maneira semelhantes aos outros, por mais diferentes que sejam (em origem, classe, função). Só então "essa semelhança cria a unidade da pólis grega, porque para os gregos, só os semelhantes podem encontrar-se mutuamente unidos pela Philia, associados numa mesma comunidade" (Vernant, 2011, p. 65).

A comunidade da pólis, por sua vez, se vincula a um princípio de igualdade (os isoi). Esse é outro aspecto que mostra que a pólis, enquanto comunidade, supõe uma espécie de philia ou amizade, em outros termos, a comunidade é "philikon", como salienta Wolff (1999) em sua leitura de Política. A 
comunidade política, ao se propor uma finalidade comum, não pode por princípio contrariar ou entravar os traços constitutivos da amizade, sob o risco de ser conduzida pela tese sofista que rebaixa a comunidade a um tipo de convivência banal, aliança ou contratualismo baseados na mera garantia de sobrevivência individual. Para Aristóteles, a liberação do desenvolvimento dos traços de philia estabelece contra essa tese o mote da busca da vida feliz (eudemonismo). Por definição, a pólis forma-se não apenas para assegurar a vida, mas para assegurar uma vida melhor. Lembremos que "[...] É evidente, portanto, que uma cidade não é apenas uma reunião de pessoas num mesmo lugar, com o propósito de evitar ofensas recíprocas e de intercambiar produtos". Ainda que sejam propósitos presentes, isso não constitui a pólis. Para Aristóteles, uma pólis se fundamenta na "união de famílias e de clãs para viverem melhor, com vistas a uma vida perfeita e independente. [...] Tudo isso [que leva ao convívio] é obra da amizade, pois a amizade é a motivação do convívio" (Aristóteles, 2000, III, 5).

Aristóteles tem um motivo profundo para fazer da amizade a mais alta virtude ética. Pela ética, se educa o desejo e se ensina o valor da autonomia, que é o ideal da autarquia, ou seja, "a autossuficiência e a independência para existir, agir, julgar, o ideal mais alto da ética e da política porque significa liberdade" (Chaui, 2002, p. 496). Ninguém é autossuficiente só. Somente o primeiro motor imóvel é autárquico, somente o deus é totalmente autossuficiente e, por isso, plenamente feliz e bem-aventurado, ressalta Chaui. "Os homens não podem ter essa plenitude, mas podem desejá-la (e a desejam) e podem imitá-la, isto é, emulá-la e simulá-la. Como os homens imitam a autarquia divina? Pela amizade", ensina Chaui (2002, p. 462). Em Aristóteles, a ação humana imita a autarquia divina; a pólis imita a autarquia do kósmos. Constituindo comunidades de ajuda recíproca e desinteressada reunidas pela pólis, as 
amizades "[...] fazem com que cada um seja mais independente do que se estivesse só” (Chaui, 2002, p. 462). Se a pólis existe em nome da autarquia, o laço da philia não implica em nenhuma contradição. Muito pelo contrário, a philia se mostra como condição da autarquia.

$\mathrm{Na}$ visão dos gregos antigos, o isolamento em relação à pólis é tão inconcebível quanto insuportável, como fica evidente na instituição do ostracismo. A ideia de que a pólis se estabelece como o lugar imprescindível do exercício e da definição das virtudes constitui uma verdade para as mais distintas visões presentes em Atenas, inclusive para as quatro principais - a dos sofistas, a de Platão, a de Aristóteles e a dos grandes autores da tragédia como Sófocles (MacIntyre, 2007). Como exprime esse bastião da tragédia grega, o exílio não denota apenas estar desprovido da companhia da humanidade. Sentir-se exilado simboliza ser privado do próprio status de ser humano. 104 Nesta passagem da tragédia de Filoctetes, essa condição indigna fica bem ilustrada: "Vocês me deixaram sem amigos, solitário, sem uma cidade, um cadáver entre os vivos" (MacIntyre, 2007, p. 135, tradução nossa).

MacIntyre ressalta não se tratar apenas de retórica. "Para nós, a noção de amizade, companhia e cidade-estado como essenciais componentes da humanidade é estranha”. É como se existisse uma grande fenda conceitual entre antigos e modernos. MacIntyre lembra que a palavra "solitário" (erêmos) é ancestral da palavra eremita, que para o cristianismo, antes da formação do liberalismo, consistia em um dos mais importantes tipos de vida humana. Embora no universo de Sófocles sejam contestadas várias visões filosóficas, "amizade, companheirismo e cidadania são aspectos essenciais da humanidade e não contestáveis" (MacIntyre, 2007, p. 135, tradução nossa).

Em sociedades heroicas como a grega, em que a relação de família, parentesco, vizinhança conta muito, a amizade 
apresenta-se como uma virtude de relevância. MacIntyre considera que o leitor moderno está completamente alheio da conexão íntima existente entre conceitos de coragem e virtudes aliadas de um lado, e os conceitos de amizade, destino e morte, de outro. Como destaca, a coragem é importante não simplesmente como virtude individual, mas como qualidade necessária para manter a família e a comunidade. "Ser corajoso é ser alguém em quem se pode depositar confiança. Por isso, coragem é um importante ingrediente da amizade. Os vínculos da amizade em sociedades heroicas são moldados naqueles de parentesco" (MacIntyre, 2007, p. 122, tradução nossa). Nesse contexto, a amizade também se origina na declaração de promessa, envolvendo imediatamente um conjunto de deveres mútuos. A coragem do amigo garante ajuda ao amigo e à sua família. A fidelidade é garantia básica de unidade na família, tanto mais para as mulheres. "Andrômaca e Heitor, Penélope e Odisseu são amigos (philos) tanto quanto são Aquiles e Pátroclus”, ilustra MacIntyre (2007, p. 124, tradução nossa). Nessas sociedades, a morte é um tema frequente, e a vida, frágil e valiosa. A vingança da morte de alguém é quase sempre prometida por um amigo ou irmão. Na concepção do autor, não se pode falar em sociedades heroicas sem falar em estrutura social e sem considerar a importância das virtudes heroicas. Não observados os códigos de honra e generosidade e as obrigações sociais recíprocas, o indivíduo corre o risco de se apartar da comunidade, a viver, como observa Polanyi em $A$ grande transformação, como um pária (Bevort, 2007).

Essa rede de deveres estabelecida entre amigos é evidente na estrutura social ateniense. Konstan menciona, por exemplo, que os gregos pensavam que as pessoas deviam perder seus amigos em caso de tratá-los mal, como quando não prestam assistência em momentos de emergência. "A amizade impunha obrigações éticas que, de modo compreensível, eram muitas vezes ilustradas em termos 
econômicos”, afirma. De qualquer forma, Konstan ressalta o traço da generosidade para qual Aristóteles chama a atenção. "Mas quando Aristóteles registra a opinião comum de que até os ricos precisam de amigos, explica que eles devem ter espaço para a liberalidade [...]" e, portanto, "não sugere que eles armazenem aliados contra uma futura mudança de sorte" (Konstan, 2005, p. 116).

Konstan evidencia um aspecto muito importante para a compreensão moderna da philia: a questão da reciprocidade. Segundo o estudioso, a ética da amizade não se confunde com a ética de graça (kháris) enraizada na comunidade ateniense, que leva a considerar um favor como uma dívida ou obrigação de retorno de algum serviço (o sentido de gratidão). A regra de reciprocidade ou retribuição em troca de favores ou benefícios concedidos era rigorosa, explica Konstan. Mas essa noção de kháris se relaciona com a prática da amizade, "não era especificamente associada com as rela106 ções entre phíloi”. Kostan (2005, p. 118) lembra o célebre adágio atribuído a Pitágoras de que "as posses dos amigos são comuns", para asseverar que "as relações entre amigos (em oposição a vizinhos, proprietários de terras, parentes e assim por diante) parecem ser precisamente a área que está isenta de tais expectativas de retorno justo [...]. Na amizade, é o compartilhamento que prevalece". Ele ainda explica: entre amigos, há sim expectativa de ajuda, generosidade (livre e espontânea), mas não necessariamente compensação.

$\mathrm{O}$ ideal de generosidade entre os amigos afasta a possibilidade de conceber as relações de intercâmbio econômico (comércio), bem como as alianças políticas (partidárias) como formas de amizade. Nesse sentido, na visão de Konstan, a amizade entre phíloi se constituía, em princípio, como espécie de "espaço de intimidade pessoal e afeição desinteressada”, não se confundindo com as normas de regulação da vida pública e comercial. Os "laços pessoais 
e de lealdade" constituídos pela philia, mais do que os interesses de classe ou de política nacional, fundamentam a atividade política. Isso quer dizer que "toda a coletividade de cidadãos livres da pólis se relacionava à maneira de uma amizade. Assim a política veio a ser considerada como o meio para o exercício da amizade" (Hunter, 1978 apud Konstan, 2005, p. 88). ${ }^{4}$ Cabe destacar que o ideal de generosidade cultivado pelo laço de philia buscava afirmar uma relação entre iguais, que tem como primazia resistir à dependência social ou econômica: "a amizade era constituída como uma esfera livre de dominação e subordinação, e com respeito a isso era um paradigma das relações de democracia”, assinala Konstan (2005, p. 119). Se a philia subentende a consciência de si por meio da consciência comum de existência, a política constitui a prática da pólis que se tornou consciente de si própria.

\section{0 que a philia nos diz sobre o fundamento da democracia}

\section{A philia como paradigma da democracia ateniense}

A instituição do ostracismo na pólis democrática tem como atribuição manter o traço de generalização da igualdade afirmado na comunidade pela philia. Sendo um pensador não democrata, Aristóteles discorda da condenação de homens qualificados por ele como proeminentes. Ele considerando que "estas cidades punham a igualdade acima de tudo, a ponto de condenar ao exílio homens tidos excessivamente poderosos por sua riqueza ou popularidade, ou alguma outra forma de força política, banindo-os da cidade por tempo determinado" (Aristóteles, 2000, III, 8). Assim, por princípio, o ostracismo foi instituído para evitar aquele que pretende se perpetuar ambiciosamente no poder, ainda

\footnotetext{
${ }^{4}$ Konstan assevera que amigos íntimos podem circunstancialmente se manter unidos na política, o que é diferente de dizer que redes de amigos íntimos eram a base da atividade política na democracia.
} 
que possa ter sido utilizado como recurso para fins particulares. Afastar o risco da tirania equivale a manter a possibilidade de conflito de ideias e de antagonismo de forças que fazem parte do traço agonístico da cultura grega. Ilustrado pelo ideal do guerreiro homérico, o agonismo visa à superação das condições de contingência e à realização da excelência humana. Visto como uma medida extrema, o ostracismo tem por objetivo repelir a centralização do poder e afastar a pretensão de hegemonia que obstaculizam o agonismo. "O ostracismo não era um castigo, mas uma precaução tomada pela pólis contra um cidadão que se suspeite vir a algum dia perturbá-la”, considera o historiador francês oitocentista, autor de A cidade antiga, Fustel de Coulanges (1998, p. 250).

Na pólis grega, a igualdade, pressuposto da philia, não suprime o agonismo. Como sintetiza Vernant (2011), a rivalidade na ordem agonística grega se coaduna com a igualdade, uma vez que a concorrência só pode existir entre 108 iguais. Esse espírito igualitário é um dos traços que aparece já na mentalidade da aristocracia guerreira da Grécia Antiga. Vernant (2011, p. 50) entende que ela "contribui para dar à noção de poder um conteúdo novo”. Como frisa Veyne (1984, p. 62), a guerra, na época clássica, representa a metade da vida de um cidadão. O poder de conflito (eris) e o poder de união ( philia) marcam dois polos da vida social no mundo aristocrático. "A exaltação dos valores de luta, de concorrência, de rivalidade associa-se ao sentimento de dependência para com uma só e mesma comunidade, para com uma exigência de unidade e de unificação sociais", afirma Vernant (2011, p. 49). Essa unidade ou comunidade, reforçada pela philia, não deixa de incorporar uma carga de agonismo e antagonismo.

Vernant menciona que o ágon está presente na política também na forma de disputa oratória, isto é, no combate de argumentos na ágora. Por isso mesmo a igualdade na philia não pode ser associada em primeiro plano à unidade 
perfeitamente harmônica, como geralmente o é. Apesar de a philia supor que somente os semelhantes estão mutuamente unidos (a semelhança tece certa unidade da pólis), os "semelhantes" distinguem-se em origem, função, classe etc. Esses semelhantes (hómoioi) membros da pólis serão definidos também, de maneira mais abstrata, como iguais (isoi). "O vínculo do homem com o homem vai tomar assim, no esquema da cidade, a forma de uma relação recíproca, reversível, substituindo as relações hierárquicas de submissão e de domínio”, explica Vernant (2011, p. 65).

O ideal de isonomia, a igual participação de todos os cidadãos no exercício do poder político, se faz presente desde a origem da pólis. Segundo Vernant, a isonomia e a isocracia serviram a círculos aristocráticos na constituição de regime oligárquico em oposição ao poder absoluto de um só (monarquia ou tirania). Esse regime era reservado a um pequeno número de homens que partilhavam a arché de maneira igual entre os membros da elite, excluindo evidentemente a massa. Essa configuração de poder, baseada na igualdade restrita a um pequeno número, inspira mais tarde as reformas de Clístenes, se estendendo em alguns momentos a todo o demos, adquirindo assim "valor plenamente democrático" (Vernant, 2011, p. 65). A reivindicação popular de isonomia, isto é, o livre acesso do demos a todas as magistraturas vai ganhar força. Para Vernant (2011, p. 66), essa exigência se generaliza “[...] sem dúvida porque se enraizou numa tradição igualitária muito antiga [...] porque correspondia mesmo a certas atitudes psicológicas da aristocracia dos hippeis", essa nobreza militar que estabelece equivalência entre qualificação guerreira e direito de participar nos negócios públicos. As reformas constitucionais implementadas por Sólon iniciam a criação de um espaço para igualdade (isotes). "Sem isotes, não há cidade porque não há philia", frisa Vernant. Solón via essas reformas no âmbito da produção de igualdade como essenciais à pólis, 
pela razão principal de que "o igual não pode engendrar guerra” (Vernant, 2011, p. 98).

Nesse momento da política ateniense, essa igualdade (isotes) apresenta, no entanto, uma natureza hierárquica ou geométrica. A chave para compreendê-la, frisa Vernant, é a noção de proporção. De acordo com essa noção, a cidade, concebida como um cosmos, torna-se harmoniosa quando seus componentes ocupam determinado lugar numa proporcionalidade e se sua porção de poder está em função de sua própria virtude. Não há, por exemplo, direito igual à propriedade de terra (Vernant conta que Sólon vangloria-se em poema por não ter implementado a isoimoria). Desse modo, a igualdade consiste na lei fixada como a mesma para todos os cidadãos, podendo os membros da pólis participar dos tribunais e da assembleia. Não é mais o ânimo dos ricos ou a força dos fortes que regulam as relações sociais. Almeja-se aí a norma da equidade, o equilíbrio (sophrosyne), 110 a concórdia (homónoia) por meio de proporções fixadas e de certa igualização das relações no tecido social.

De Sólon, passando por Clístenes e chegando a Péricles, ocorre um desenvolvimento mais acentuado dessas mudanças políticas (o avanço da isonomia ou igualdade de participação; a isegoria ou o direito de liberdade e igualdade no uso da palavra na assembleia; a mistoforia ou pagamento por funções públicas que viabiliza a participação na bulé pelos cidadãos mais pobres etc.). Pressuposto da philia, o espírito de comunidade se amplia na instituição de medidas de igualdade. Dos círculos aristocráticos ao demos da democracia: a philia, restrita inicialmente a um círculo pequeno de nobres homens, se alarga definitivamente incluindo o demos. Na visão de Finley (1988), a progressão da direção igualitária dessa comunidade foi o motor essencial para o sucesso da democracia ateniense.

Se a extensão da philia à pólis em geral suscitou dificuldade, o que dizer sobre a ampliação de traços da philia à pólis 
democrática? Mais uma vez, não é uma questão de quantificação, como se o problema orbitasse em torno de um demos maior ou menor. A questão é que a philia diz respeito à forma de integração na comunidade, marcada pelos pressupostos de uma comunidade de iguais. Quanto a isso, não parece ser coincidência o fato de a expressão philia, segundo Macherey (1995), entrar em maior uso no fim do século V a. C., o chamado Século de Péricles. Em Ética a Nicômaco (1987), Aristóteles concebe as formas políticas (aristocracia, monarquia, democracia) em função de sua organização ou disposição de relações, que por sua vez seguem modelos diferenciados de integração à comunidade. Nesse sentido, cabe assinalar como a philia oferece elementos para compor a prática democrática ateniense.

Se a philia se consolida como paradigma das relações de democracia, é precisamente porque opera no interior da pólis tomando a forma de regimes políticos capazes de produzir mais ou menos efeitos de igualização, de vida em comum, de neutralização das relações de dominação. O modo de integração à comunidade concerne ao movimento de tecedura, isto é, de constituição do tecido comunitário. Etimologicamente, a philia supõe esse trabalho de tensão, que corresponde à experiência de criação de proximidade com pessoas diferentes de mim, consequente à produção de acordo, de algo em comum (Vernant, 1995, p. 197). A extensão desse entrelaçamento, dessa associação ou comunidade, torna-se a medida de produção de direitos. Assim como "os amigos têm tudo em comum", toda comunidade dá origem a relações de direito.

Mobilizemos a concepção aristotélica de que em toda forma de comunidade encontra-se alguma forma de amizade (e, por consequência, de justiça) (Aristote, 1987, VIII, 9). Dito de outro modo, toda amizade implica uma espécie determinada de comunidade (Aristote, 1987, VIII, 14). A extensão dessa associação corresponde à medida da 
extensão da amizade, o que determina também a medida de direitos (caráter da justiça) (Aristote, 1987, VIII, 11). Desse modo, pode-se perceber que comunidades políticas que entravam a amizade obstaculizam a expansão da comunidade, a ampliação dos direitos. Por isso considera que não pode haver amizade onde nada aproxima o governante dos governados - e nesse caso, não há também justiça (Aristote, 1987, VIII, 11). É o caso das tiranias, nas quais tanto amizade quanto justiça inexistem ou, se existem, é em grau mínimo.

Em Antígona, por exemplo, Creonte teme conspirações entre grupos de amigos, o que o caracteriza explicitamente como um tirano. Como lembra Konstan (2005, p. 97), a amizade sendo considerada uma virtude não pode ser tomada, pelos governantes, como uma ameaça. É um absurdo a lealdade de amigos ser vista como subversão. Mais tarde, Cícero, em Sobre a amizade, afirma não existir amizade onde há tiranos. Wolff considera, aliás, que a cidade sem amizade é boa 112 para o despotismo, lugar do medo e da completa ausência de amizade. Nela, "o povo pode então ser comparado a esta multidão bestial e desnaturada, pior que cada um de seus membros" (Wolff, 1999, p. 138).

A democracia é apontada por Aristóteles como aquela forma política em que a amizade (e com ela, a justiça) apresenta maior intensidade. A amizade pode ser mais ou menos intensa de acordo com o número e a importância das coisas postas em comum. Assim, o filósofo avalia que entre irmãos é presumível haver uma comunidade total e, por conseguinte, uma amizade intensa. Na democracia, supõe-se haver igualdade entre cidadãos, julgando-se então haver muita coisa em comum (Aristote, 1987, VIII, 11). Como interpreta Fraisse (1974, p. 200, tradução nossa), "é a vida comum que, efetivamente realizada, permite a philia se espalhar". Esse modo de pensar a democracia autoriza a pensá-la como a forma mais autêntica não só da comunidade política, bem como da amizade política (Aguiar, 2015). 
Nesse sentido, também podemos derivar de Aristóteles, ao mesmo tempo a favor e a despeito de seus escritos, que a democracia tende a ser a mais natural forma de promover a concórdia, uma vez que esta é concebida como a própria amizade política (Aristote, 1987, IX, 6). A prática da philia, isto é, a disposição para pôr as coisas em comum, para estabelecer a igualdade e para propiciar a formação da consciência autônoma, constitui o melhor remédio para as sedições da pólis e os conflitos civis. A verdadeira pacificação da pólis encontra-se, sob essa perspectiva, na intensificação da philia (Aristóteles, 2000, II, 4), de preferência, no interior da democracia. Da mesma forma, consolidar a concórdia confere o ideal do legislador e, portanto, se refere a suscitar a amizade entre cidadãos (Aristote, 1987, VIII, 1). Assim, a amizade é, antes da justiça, o objeto de principal preocupação. "Quando os homens são amigos não necessitam de justiça, ao passo que se eles se pretendem justos necessitam ademais de amizade; a mais alta expressão de justiça é, na opinião geral, uma espécie de amizade" (Aristote, 1987, VIII, 1, 1155 a 25-30, tradução nossa).

Quando assimilamos de Aristóteles a existência de uma íntima relação entre philia e democracia, precisamos explicar a condição de escravos ${ }^{5}$ e mulheres. Quem diz pólis diz philia, comunidade e igualdade. Ora, como vimos, o princípio da philia se estende dos círculos aristocráticos ao demos, dando origem à democracia que converte trabalhadores pobres em homens livres, iguais e semelhantes. Mas esse avanço esbarra em limites, não se estendendo, porém, à massa dos escravos e mulheres. Para Aristóteles, as amizades entre aqueles de escalão desigual (marido e mulher, sábio e ignorante)

\footnotetext{
${ }^{5}$ Apesar de apontar no escravo grave deficiência - ele obedece e compreende racionalmente, mas é desprovido de deliberação - o filósofo afirma poder haver amizade com o escravo na medida em que ele é um homem (não na medida em que é escravo), pois sendo homem que participa da lei e do contrato existe algo de justo nele (ARISTOTE, 1987, VIII, 13 1161b 5-8).
} 
(Aristote, 1987, VIII, 10), bem como entre homens livres e escravos (Aristote, 1987, VIII, 13) designam amizades de tipo inferior e não as amizades virtuosas (o télos na pólis). Tocamos em um ponto nevrálgico. Se a pólis constitui uma comunidade no meio da qual a philia se espalha, estabelecendo um espaço de exercício de virtude, excluir escravos e mulheres pela suposta incapacidade de deliberação e de mando parece uma justificativa insatisfatória. Como explica Fraisse (1974, p. 210), a amizade desempenha o esmaecimento da desigualdade. Ora, como comunidade política a pólis tem precedência sobre as demais comunidades. No entanto, a pólis é plural e não "um”: "toda comunidade é como que uma fração da comunidade política" (Andrade, 2015, p. 119). Logo, bem frisa Andrade, conceber a integração de escravos e mulheres na pólis e a exclusão da politeia, a subordinação dos não cidadãos à hegemonia dos cidadãos, produz uma tensão no pensamento de Aristóteles.

114 Devemos ainda repetir a pergunta que Andrade (2015, p. 106-107) se faz: "dada a importância do comum (koinós) para a compreensão da pólis", não podemos considerar a presença "de mais agentes no espaço político do que simplesmente o grupo de cidadãos que 'governa', ou seja, pratica a pólis"? Isso equivale, por exemplo, a pôr em relevo o interesse "comum", em vez do "público" e do "privado". Nesse sentido, a historiadora argumenta que constitui uma tarefa importante explorar a pluralidade da pólis, produzindo uma mudança de perspectiva que lança olhar ao espaço doméstico (oikos) na tentativa de conferir em que medida a hegemonia dos cidadãos realmente se reproduz nesse âmbito, em que medida os "não cidadãos", por exemplo, as mulheres que Aristóteles considerava viventes políticos sem direito ao exercício do poder, se associavam, interagiam, influenciavam a prática da pólis pelos cidadãos (politês). Definitivamente, a pólis não era exatamente uma instituição estatal a governar uma população, como fica 
sugerido na expressão cidade-estado. E isso faz diferença. Como argumenta Andrade (2015, p. 111), Aristóteles não coloca o tema da "ordem" da pólis (taxis) como uma questão de "controle ou gestão de uma população". O seu enfoque orienta-se para o problema de produzir "a boa pólis, autárquica, por bons cidadãos".

Se a democracia ateniense estende-se, de forma inédita, até o demos, esse vasto grupo de trabalhadores pobres, mas sem integrar, no entanto, a massa de escravos e mulheres, é porque o processo pelo qual uma "sociedade" se faz "comunidade" não é uniforme. Assim, ao longo de quase dois séculos de democracia, várias desigualdades continuam persistentes na sociedade grega. De todo modo, Veyne ressalta que a democracia grega opera uma "ruptura" entre o plano social e político, ruptura essa que vem acompanhada de intensa politização dos cidadãos. Apesar dessa politização, esses homens seguiam submetidos a forças econômicas e a relações sociais inarredáveis. A obrigação moral do cidadão, por exemplo, prossegue determinando o dever de envidar esforços e recursos à disposição da comunidade. É o caso do rico que distribui riqueza como forma de legitimá-la e pratica a beneficência (ex.: o mecenato) como uma motivação cívica (Veyne, 1984, p. 59-60).

Veyne nota que a democracia suscita no povo o orgulho de poder opinar sobre os negócios públicos e até sobre os interesses econômicos. Mas o respeito à superioridade social dos notáveis, os mais ricos e influentes permanece. "Compreende-se então o que foi essa democracia: para o povo, sua participação na política foi uma espécie de questão de honra, de maneira de afirmar sua dignidade em face dos poderosos" (Veyne, 1984, p. 67). Aos olhos de Mossé (1998), fica claro, por exemplo, que a desigualdade de fato presente no seio da comunidade muitas vezes "limitava a igualdade de direito". Ele pondera que a democracia ateniense, com efeito, aplica diversos paliativos que estabelecem limites às 
desigualdades, citando as medidas que favorecem a participação política dos mais pobres (a mistoforia), que suprimem a dependência dos camponeses, que sobrecarregam os ricos com despesas públicas, que minimizam as influências e o clientelismo na política (a prática do sorteio).

Se por um lado a igualdade é "mais teórica do que real", Mossé (1998, p. 255), frisa que o sentimento de igualdade sentido pelos atenienses, somado às medidas tomadas contra a extrema pobreza, explicam a longa duração da democracia grega. Essa democracia guerreira forjada no seio de uma sociedade heroica deu forma a um movimento de militância, o demos ocupando de agora em diante a ágora, as assembleias e os júris em razão de um direito cívico, submetendo muitas vezes os ricos à jurisdição popular (o que era motivo de satisfação) (Veyne, 1984). Veyne afirma que essa democratização produz um "movimento centrífugo", pelo qual a própria instituição política mobiliza o demos como ativista.

116 Nesse corpo cívico, o governante constituía apenas mais um cidadão, sendo quase irrelevante distinguir o "governado" do "poder público", já que as posições não são cristalizadas e a alternância é constante (Veyne, 1984, p. 59-60).

Embora a democracia ateniense não se estenda a escravos e mulheres, ainda assim ela constitui uma experiência inédita na história das práticas políticas. A democracia, entendida na verdade como um movimento, isto é, como democratização, é impulsionada sempre que a philia é desencadeada. Como ressalta Veyne, no interior da vida greco-romana, assim como em todas as sociedades, operam "pressupostos" ou "discursos" (no sentido de Foucault) muitas vezes ignorados que lançam imperativos até certo ponto seguidos ou obedecidos. Digamos que a philia, como uma das mais altas virtudes, constitua um desses pressupostos. Se a democratização segue o compasso da intensificação da philia, podemos dizer que a experiência grega se destaca 
particularmente pelo escopo ético-político de uma demofilia (Aguiar, 2015).

\section{Os traços recônditos da philia na democracia moderna}

Com o Cristianismo, a philia, ou amizade, no sentido estudado, passa por consideráveis mutações, chegando à modernidade dotada de uma natureza completamente distinta. A amizade perde força em favor do amor no sentido da caridade (ágape), entendida por São Tomás de Aquino, em Suma Teológica, como a amizade do homem com Deus. A amizade torna-se, definitivamente, assunto de pensadores da Antiguidade, "malgrado as homenagens prestadas por pensadores modernos e contemporâneos à amizade" (Fraisse, 1974, p. 170, tradução nossa). Nos círculos filosóficos e políticos, torna-se um assunto quase que exclusivamente pertencente à esfera da ética e, como tal, não mais vinculado ao plano político. A modernidade constitui todo um outro mundo de referências, de valores, de práticas, por isso, seria anacrônico buscar na amizade moderna a essência antiga da philia. A amizade agora se circunscreve exclusivamente à esfera de vida privada dos indivíduos, vista como "charme" ou "luxo da vida moral", nas expressões de Macherey, não designando nem necessidade nem instituição. Na verdade, os modernos praticam e honram o amor e pouco conhecem a amizade, segundo Dugas (1894 apud Macherey, 1995, p. 59). Em busca do fio perdido da amizade, Vincent-Buffault (1996, p. 9) observa que nos séculos XVIII e XIX, momento importante para a gestação da democracia moderna, ela é "aceita, valorizada, mas não está em evidência nesse período", ela constitui "alegria suplementar, marca de uma eleição, não é instituição”. Com efeito, o amor, o casal e a família ocupam o centro das relações. À prática da amizade resta um papel acessório. Ao mesmo tempo, a amizade moderna apresenta apenas uma das várias feições da philia antiga. 
Para cada momento da história existem condições muito singulares para o exercício da amizade, assinala VincentBuffault. De certo, a philia grega registrada em Aristóteles faz parte de um tempo cujos sentidos escapam à história. Quando o tema da philia passa a se restringir à ética, ela se desnatura e o vínculo que existia entre ela e a democracia se perde, tornando-se totalmente incompreensível. É o que Veyne (1984, p. 58) incita a pensar, ao considerar que a política de diferentes épocas tenha subentendido "pressupostos que escapavam à consciência dos agentes; que escapavam igualmente à posteridade, muito apressada em reencontrar-se em seus ancestrais, mesmo que seja banalizando os traços de sua fisionomia”. Torna, assim, imperceptíveis as enormes diferenças.

Como se sabe, o modelo greco-romano povoou o imaginário moderno, desde o Renascimento passando pelo Iluminismo, no campo revolucionário e conservador. 118 Canfora observa que a cidade antiga constituiu um laboratório da política que deixou enorme legado de documentos escritos. A partir de conflitos e interesses contingentes ou decorrentes dos desafios tomados pelos grupos envolvidos na disputa ideológica na França da revolução, por exemplo, foram elaborados "modelos e conceitos - e aqui está a peculiaridade daquele grande florescimento de cultura política escrita - que acabaram tendo, legitimamente, valor no plano geral: para além do significado concreto que tiveram no seu tempo" (Canfora, 2006, p. 181, grifo do autor). Nesse momento em que a democracia ateniense é mobilizada na disputa para construção da ordem política, tanto por jacobinos, liberais, quanto por conservadores, restam um Aristóteles cristianizado, uma philia transmutada em ágape e vínculos entre amizade ( philia) e democracia invisibilizados.

Nessa disputa, a amizade sai e a fraternidade entra em cena. Na linguagem revolucionária dos séculos XVIII e XIX, ela é o parente pobre da divisa revolucionária - liberdade, 
igualdade e fraternidade. Tendo dupla conotação, é identificada nos dicionários da época como "cristã, porque 'os religiosos se qualificam de irmãos'; como maçônica, porque a maçonaria acostumou as elites à prática das associações 'fraternas'” (Ozouf, 1989, p. 718). Assim, se fala do hábito das pessoas de se cumprimentarem como "irmãos" e "amigos”, hábito esse que data de abril de 1791, e do costume em assinar "salvação e fraternidade" nas epístolas das sociedades, além da prática de tutear (tratar por tu e não por vós) difundida como sinal de "inclinação à fraternidade" (Ozouf, 1989, p. 721). Na linguagem revolucionária aparecem fundidas, portanto, a noção cristã da amizade com Deus (antítese do ideal da igualdade entre amigos da Antiguidade clássica), e a ideia de amor fraternal, sendo todos os homens filhos de Deus, em prol da fraternidade e do amor universal (Aguiar, 2015). Mas o sentido da amizade não estava presente furtiva e desnaturadamente só nos cumprimentos de revolucionários franceses ou na saudação do digger Winstanley às autoridades superiores como fellow-creature (um companheiro, um igual) no século XVII. Os pressupostos da philia, na verdade, modernizados e em versões atualizadas, estiveram em maior ou menor medida presentes na pauta de reformadores e revolucionários, filósofos e políticos modernos, fazendo da democratização uma experiência tão descontínua quanto insuprimível.

No século XX, pensadores começam, com alguma consistência e senso crítico, a se voltarem para a relevância da amizade na política e, em especial, na democracia, como Arendt, Foucault e Derrida. Suas críticas deram conta de apresentar as limitações da fraternidade, bem como retomar criticamente a amizade como matriz ético-política para a democracia. Arendt afirma ser a amizade requisito fundamental para o bem-estar comum na cidade, em oposição à interpretação que restringe a philia aristotélica à ausência de facções e guerra civil. Para a autora, o esmaecimento do 
sentido presente na philia grega sinaliza o desaparecimento do "mundo comum" na modernidade (nos seus termos, a partilha do mundo com outros homens, o falar-junto, o intercâmbio nas conversas), a amizade não mais é associada a exigências políticas (Arendt, 2008). Foucault compreende a amizade sob a ótica de uma estética da existência. Não se interessa pelo modelo institucionalizado das relações de $p h i$ lia, porque entende que ele bloqueia caracteres transgressores, mas se interessa em reintegrar o eros à dinâmica da amizade que teria sido separado da philia desde a Antiguidade (Ortega, 1999, p. 159).

Derrida (1994b), por sua vez, mostra como o horizonte da fraternidade se enraíza na família (associado ao tema nacional, sangue, solo e autoctonia), na virilidade (vinculado ao engrandecimento da virtude viril dos filhos da nação) e no que chama de androcentrismo propriamente ancestral, relativo à dificuldade em projetar a igualdade civil 120 entre homens e mulheres. Ancestral porque presente deste a matriz greco-romana na própria amizade. Derrida expurga o ideal de fraternidade e critica os ranços androcêntricos da philia. Não propõe a retomada anacrônica da philia aristotélica, mas a eleição de alguns elementos seus como a igualdade e a suplantação da utilidade e do prazer. Restabelece assim a amizade no campo da filosofia política, mobilizando a noção de que tudo o que é político envolve necessariamente amizade, e tudo o que tem de amizade envolve o político (Derrida, 1994a, 1994b).

Nas últimas décadas, reflexões e práticas têm apontado para necessidade cada vez mais urgente de continuação da reinvenção da democracia, de modo a enfrentar, sobretudo, a desigualdade desenfreada, a fragmentação individualista e a mercantilização total da vida (negadoras, respectivamente, da igualdade, da comunidade e da autonomia). Capitalismo contra democracia: as sociedades contemporâneas suscitam a crítica aristotélica às amizades utilitárias próprias de 
espíritos mercantis. Essa ordem foi capaz de reinventar uma espécie de ostracismo moderno, aquele que se vive dentro da própria sociedade, deixando homens sem amigos, sem companhia, cadáveres entre os vivos.

Caracterizadas pela dissolução dos corpos sociais tradicionais (família, comunidade, povo, igreja, nação, pátria) e pelo declínio das organizações cívicas e comunitárias, as sociedades passam pelo colapso da ordem social moderna. Como formulam Hardt e Negri (2016), a instabilidade em vigor mina o caráter de confiança, lealdade, compromisso mútuo, laços de família etc. Nesse momento, um conjunto amplo de autores e atores políticos, entre eles Dardot e Laval (2017) e Hardt e Negri (2016) põe no primeiro plano da imaginação teórica a recriação do conceito de comum, na melhor tradição da philia. Reatualizada, a noção do comum acompanha a tentativa de intensificar ou radicalizar a democratização sempre ameaçada, fazendo a "cidade" autocriar-se (a comunidade não é dada, ela é uma autocriação, melhor disse Castoriadis), reinventando os negócios comuns, recriando vínculos sociais conforme o espírito da philia-amizade, tentando dar a si o seu próprio sentido e finalidade (esforço de autarquia), dito de outra forma, retomando o impulso de uma demofilia. Essa tradição assume o campo ético como campo de disputa para a democracia, distinguindo-se de teóricos como Mouffe (2013), para quem a questão dos princípios éticos não seria mais um problema para a democracia (para essa autora, o problema está na interpretação desses princípios, bem como em sua aplicação ou realização na prática).

\section{À guisa de conclusão}

Na tentativa de explorar os sentidos da philia formulada na obra de Aristóteles, derivamos a partir desse conceito três pressupostos, quais sejam: a) ver o outro como o meu igual (igualdade); b) a vida em comum ou o pôr as coisas em comum (comunidade); e c) a ampliação da consciência de si 
na consciência da existência comum (autonomia). Aristóteles concebe a existência de uma maior afinidade entre philia e democracia, uma vez que nessa forma de governo supõe-se haver mais coisas em comum. Se quem diz pólis, diz philia, diz comunidade, sugerimos que a democracia mostra-se como a forma mais autêntica da comunidade política.

A philia, ou amizade, parece compor a condição de constituição da autarquia da pólis, reafirmando que ninguém se torna autossuficiente estando só. "Nesse sentido, o que os atenienses nos legaram de mais geral, a tradição da democracia grega, é o que eles tinham de mais particular, o que firmava o laço de sua comunidade", afirma Vidal-Naquet (2012, p. 29). Essa abordagem inscreve na democracia um conteúdo ético-político, que tanto golpeia o contratualismo sofista de seu tempo, quanto municia contra o projeto processualista da democracia contemporânea, dissociada de ideais (Finley, 2012). Dessa maneira, pensar a política na 122 pólis constitui pensar para além de um problema de governo: é produzir forma de organização da vida verdadeiramente comum (Bevort, 2007). Em seus seminários de 1983-1984 (A cidade e as Leis), Castoriadis retoma a ideia aristotélica de que o tirano não suporta a philia. Para ele, o tirano quebra todas as amizades e reduz a comunidade à "poeira de indivíduos" para assim reinar e se consolidar como único centro de referência e de unificação do poder. Isso demonstra que a philia depende da instituição política da cidade, pois é ela que estabelece os indivíduos como iguais, que favorece a prática da virtude e que produz novas condições de reprodução das amizades.

Ao espelhar a philia como pressuposto na democracia moderna, corre-se o risco de cair na armadilha dos anacronismos e de julgar a sociedade dentro das balizas de princípios da Antiguidade. Mas não se trata de repetir a experiência ateniense, como se fosse ela a eterna verdade inscrita na origem, mas derivar dessa experiência o que caracteriza 
propriamente a democracia, isto é, o movimento de progressão que percorre da philia aristocrática à philia democrática, na reinvenção constante da igualdade, do comum e da autonomia em oposição à dominação. As condições modernas e contemporâneas impõem novos desafios à reinvenção da democracia. São condições desconhecidas da Antiguidade, que têm no centro forças fundadas no indivíduo (individualismo liberal), no capital (capitalismo) e no Estado (estatismo), para a qual não pode dar soluções. Mas os pressupostos da philia persistem ao longo dos tempos, sendo reformulados e recriados, no movimento de impulso da democratização.

\section{Thais Florencio de Aguiar}

é professora do Departamento de Ciência Política da Universidade Federal do Rio de Janeiro (UFRJ). Rio de Janeiro, Rio de Janeiro, Brasil.

\section{Bibliografia}

AGUIAR, Thais Florencio de. 2015. Demofobia e demofilia: dilemas da democratização. Rio de Janeiro: Azougue Editorial.

ANDRADE, Marta Mega. 2015. Pólis: comunidade, política e a vida em comum numa leitura da Política de Aristóteles. Classica: revista brasileira de estudos clássicos, v. 28, n. 1, pp. 95-124.

ARENDT, Hannah. 2008. Homens em tempos sombrios. São Paulo:

Companhia de Bolso.

ARISTOTE. 1987. Éthique à Nicomaque. Traduction, introduction, notes et index par J. Tricot. Paris: Librairie Philosophique J. Vrin.

ARISTÓTELES. 2000. Política. São Paulo: Nova Cultural. (Coleção Os Pensadores).

AUBENQUE, Pierre. 2003. A prudência em Aristóteles. São Paulo: Discurso Editorial.

BEVORT, A. 2007. Le paradigme de Protagoras. Revue Socio-logos, n. 2. Disponível em: https://bit.ly/2KjM29z. Acesso em: 20 out. 2017. BITTENCOURT, Renato Nunes. 2010. A questão da agonística grega e suas influencias na formação da cultura ocidental. Revista Urutágua, n. 22, pp. 14-30. 
CANFORA, Luciano. 2006. Como entrou e como finalmente saiu de cena a democracia grega. Estudos Avançados, v. 20, n. 58, pp. 169-188.

CHAUI, Marilena. 2002. Introdução à história da filosofia: dos pré-socráticos a Aristóteles. São Paulo: Companhia das Letras. V. 1.

DARDOT, Pierre; LAVAL, Christian. 2017. Comum: ensaios sobre a revolução no século XXI. São Paulo. Boitempo.

DERRIDA, Jacques. 24 nov. 1994a. A travers la déconstruction des grands textes, Jacques Derrida reconstitue l'histoire de l'amitié: où il en va de l'exclusion du féminin de la politique, de la justice et de la démocratie. Le cahier livres de Libération. Disponível em: http:/ / hydra.humanities. uci.edu/derrida/ami.html. Acesso em: 10 fev. 2010.

DERRIDA, Jacques. 1994b. Politiques de l'amitié: suivi de L'oreille de Heidegger. Paris: Galilée.

FINLEY, Moses. 1988. Democracia antiga e democracia moderna. Rio de Janeiro: Graal.

FINLEY, Moses. 2012. Démocratie antique et démocratie moderne. Paris: Éditions Payot.

FOUCAULT, Michel. 1994. De l'amitié comme mode de vie. Dits et Ecrits, t. IV, n. 293.

FOUCAULT, Michel. 2010. O governo de si e dos outros. São Paulo: Martins Fontes.

FRAISSE, Jean-Claude. 1974. Philia: la notion d'amitié dans la philosophie antique. Paris: Librairie Philosophique J. Vrin.

FUSTEL DE COULANGES, Numa Denis. 1998. A cidade antiga. Tradução de Fernando de Aguiar. São Paulo: Martins Fontes.

GOBRY, Ivan. 2000. Le vocabulaire grec de la philosophie. Paris: Ellipses.

HARDT, Michael; NEGRI, Antonio. 2016. Bem-estar comum. Rio de Janeiro: Record.

JANKÉLÉVITCH, Sophie; OGILVIE, Bertrand (org.). 1995. L'amitié. Dans son harmonie, dans ses dissonances. Paris: Éditions Autrement.

KONSTAN, David. 2005. A amizade no mundo clássico. São Paulo: Odysseus.

MACHEREY, Pierre. 1995. Le "Lysis" de Platon: dilemme de l'amitié et de l'amour. In: JANKÉLÉVITCH, Sophie; OGILVIE, Bertrand (org.). L'amitié. Dans son harmonie, dans ses dissonances. Paris: Éditions Autrement. pp. 43-57.

MACINTYRE, Alasdair. 2007. After virtue: a study in moral theory. Notre Dame: University of Notre Dame Press.

MOSSÉ, Claude. 1998. Dictionnaire de la civilisation grecque. Brussels: Éditions Complexe. 
MOUFFE, Chantal. 2013. Agonistics: thinking the world politically. London: Verso.

ORTEGA, Francisco. 1999. Amizade e estética da existência em Foucault. Rio de Janeiro: Graal.

ORTEGA, Francisco. 2002. Genealogias da amizade. São Paulo: Iluminuras. OZOUF, Mona. 1989. Fraternidade. In: FURET, François; OZOUF, Mona. Dicionário crítico da Revolução Francesa. Rio de Janeiro: Nova Fronteira. pp. 718-728.

TIERNO, P. 2007. Ética y política en Aristóteles: bien humano, zoion politikón y amistad. In: ROSSI, Miguel Angel. Ecos del pensamento político clássico. Buenos Aires: Prometeo. pp. 117-148.

VERNANT, Jean-Pierre. 1995. Tisser l'amitié. In: JANKÉLÉVITCH, Sophie; OGILVIE, Bertrand. (org.). L'amitié. Dans son harmonie, dans ses dissonances. Paris: Éditions Autrement. pp. 188-202.

VERNANT, Jean-Pierre. 2011. As origens do pensamento grego. Rio de Janeiro: Difel.

VEYNE, Paul. 1984. Os gregos conheceram a democracia? Diógenes, v. 6 , pp. 57-82.

VIDAL-NAQUET, Pierre. 2012. Tradition de la démocratie grecque. In: FINLEY, Moses. Démocratie antique et démocratie moderne. Paris: Éditions Payot. pp. 4-29.

VINCENT-BUFFAULT, Anne. 1996. Da Amizade: uma história do exercício da amizade nos séculos XVIII e XIX. Rio de Janeiro: Zahar.

WOLFF, Francis. 1999. Aristóteles e a política. São Paulo: Discurso Editorial. 


\section{O QUE A AMIZADE (PHILIA) NOS DIZ SOBRE OS FUNDAMENTOS DA DEMOCRACIA? PRESSUPOSTOS DE UMA "DEMOFILIA"}

\section{THAIS FLORENCIO DE AGUIAR}

Resumo: Na perspectiva de Aristóteles, a política constitui a continuação da investigação ética. Se for verdade que a philia, ou amizade, ocupa o lugar mais alto de sua ética, é preciso então voltar a atenção do pensamento político para ela. Este artigo tem como objetivo explorar os sentidos da philia formulada na visão paradigmática de Aristóteles. Trata de investigar seu caráter de fundamento da pólis grega, bem como sua afinidade com a democracia antiga. Por último, esboça os sinais recônditos da persistência dos pressupostos da philia na democracia moderna, traçando o que sugerimos como tradição da "demofilia".

Palavras-chave: Philia; Amizade; Pólis; Democracia; Demofilia.

\section{WHAT DOES FRIENDSHIP (PHILIA) TELL US ABOUT THE FOUNDATIONS OF DEMOCRACY? ASSUMPTIONS OF A "DEMOPHILIA"}

Abstract: According to Aristotle's perspective, politics constitutes the continuity of research on ethics. If it is a fact that philia or friendship occupies the highest position on his ethics system, therefore it might be essential to turn some attention of the political thought to it. This article aims to explore the meanings of philia formulated upon the paradigmatic view of Aristotle. It seeks to investigate philia's character as a Greek polis foundation, as well as its affinity with ancient democracy. Finally, it outlines the inmost signs of the persistence of philia's assumptions in modern democracy, outlining what we suggest as a tradition of "demophilia".

Keywords: Philia; Friendship; Pólis; Democracy; Demophilia.

Recebido: 27/09/2018Ａprovado: 16/07/2019 